A trust fund committee has been formed to receive moneys given for the foregoing purpose, composed of the following:- the Marquis of Anglesey (chairman), Sir William Anson, M.P., Mrs. Asquith, Mr. Balfour, Lord Justice Buckley (hon. treasurer), Viscountess Esher, Lady Meyer, Sir Arthur Rücker, F.R.S., Lady Rücker, and Dr. John Atkins (hon. secretary).

The funds will be administered in accordance with the terms of the trust deed by an executive committee composed of representatives of the donors and of King's College for Women, including the Rev. Dr. Headlam, Prof. Jackson, Dr. Miers (the principal of the University of London), Miss Oakeley, Lady Rücker, and Prof. Smithells.

Among those who have generously contributed to the fund raised for the purposes of the endowment of King's Callege for Women are:- the Marquis of Anglesey, Mrs. Asquith, the Duke of Devonshire, Sir Richard Garton, Sir Carl Meyer, Lady Mond, Mr. Almeric Paget, M.P., Mrs. Almeric Paget, the Earl of Plymouth, Messrs. Rothschild and Sons, the Marquis of Salisbury, the Earl of Scarbrough, Lady Wantage, and the Duke of Westminster.

The Times in a leading article on Saturday, May 27 warmly eulogises the new departure, which, it says, "will be received throughout the country with universal satisfaction and sympathy."

This sudden and remarkable development will be hailed with satisfaction by those who during the last two years have been engaged in carrying out in connection with King's College, under great difficulties, the first attempt made in a university institution in this country to establish a course of higher education for women, centring round home and institutional life. In spite of the unsuitable accommodation and lack of funds, a beginning has been made, and those who are in charge of the scheme are confident of its value and permanent success. Now that funds and influential support are forthcoming, the chief obstacle to progress will probably consist in the difficulty of winning the goodwill of the educational world.

It is a little unfortunate that there is no good term available for indicating the range of studies that are comprised in the King's College course. The expression "home science" is not very felicitous, and it is to be

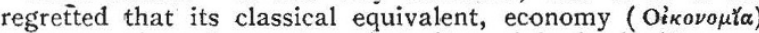
or economic science, has lost its original significance. The pleonasm, domestic economy, has, not without good reason, fallen into disrepute. But whatever be the term used, it can hardly be doubted that, as in agriculture and other crafts, long left in the empiric state, it should be possible to delimit and develop a tract of higher intellectual studies which will rationalise and inform the vastly important work of household administration.

\section{ANNUAL TABLES OF CONSTANTS AND NUMERICAL DATA.}

$\mathrm{A}^{\mathrm{T}}$ the International Congress of Applied Chemistry held in London in I909, an International Commission was appointed for the purpose of compiling and publishing annual tables of constants and numerical data, and this commission was subsequently accorded the patronage of the International Association of Academies at the meeting of that body held in Rome in I9Io (NATURE, May 26, 1910, p. 371).

According to the programme drawn up by the commission, the tables published in any one year are intended to contain all the numerical data likely to be of interest in connection with chemistry, physics, and allied sciences, pure and applied, to be found in the literature published during the previous year. The data are to be accompanied by full bibliographic references. This programme has now (May) so far matured that portions of the volume for 1910 are already in the press, while the manuscript of the remaining portions is approaching completion.

Owing to the immense volume of scientific and technical literature which is continually being produced, the difficulties in the way of finding out whether any given measurement has been made or not are increasing year bv year. Existing systems of indexing and abstracting offer only limited help, since a large number of measurements are made in the course of researches to which they are purely subsidiary, so that their existence NO. 2 I 70, VOL. 86] cannot be inferred from the titles and subtitles of the papers in which they are recorded. Also tables which appear only at long intervals, such as those of Landolt and Börnstein, can of necessity cover only a small part of the ground, and, moreover, in most cases they are hampered by the limitations of private enterprise. The annual tables should therefore fill a serious gap which has hitherto existed in the systematic indexing of scientific and technical results.

It is hoped that ultimately the enterprise may become self-supporting; but obviously this cannot be the case for some time to come. The commission has been greatly assisted by grants from various societies; for example, in this country, from the British Association, Chemical Society, Faraday Society, Royal Dublin Society, Royal Irish Academy, Royal Society of Edinburgh, and the Society of Chemical Industry. Donations have also been received from a few private persons, notably from the Earl of Berkeley, F.R.S. The financial position is, however, still far from satisfactory, and further help from societies and private donors is urgently needed. In this connection it may be mentioned that neither the general secretary nor the members of the commission receive payment for their services, except in so far as they may perform actual compiling or abstracting.

The organisation of the commission is sufficiently complete to deal effectiveiy with the periodical literature, but it happens occasionally that data are published only in non-periodical publications, such as books or monographs, and such data may easily be overlooked. Accordingly, in order that the annual tables may be as complete as possible, the authors of such books, monographs, \&c., are requested to communicate with one or other of the members of the commission. In cases where the data are numerous, specimen copies or corrected proofs of the tables containing the data would be very acceptable.

The members of the International Commission for the United Kingdom are :-Dr. Alex. Findlay, The University, Edgbaston, Birmingham; Dr. R. T. Glazebrook, C.B., F.R.S., The National Physical Laboratory, Teddington, Middlesex; and Dr. N. T. M. Wilsmore, University College, Gower Street, London, W.C. The general secretary is Dr. Charles Marie, 98 Rue du Cherches-Midi, Paris VI.

\section{STANDARD TIME-KEEPING.}

A PPARENTLY the efforts of the British Science Guild to show the commercial need that exists for a more widespread observance of standard time than exists at present (see NATURE of February 16) have already attracted some attention, for last week we had an opportunity for inspecting a demonstration of yet another clock synchronisation system, to be made available by the Greenwich Time Co., which, we believe, is either a branch or offspring of the Normalzeitgesellschaft of Berlin, where there are about 30,000 clocks under the control of the company.

The company has offices in Albany Street, N.W., where a Time Bureau is to be established, and by means of the usual arrangements with the Post Office authorities, the Greenwich time signal is transmitted to the bureau over wires provided for the purpose. This signal controls a regulator clock, the function of which is to control electrically, haif a dozen times during the day, other clocks in subscribers' premises. These clocks are arranged so as to report back their behaviour at certain times. If the synchronisation is reasonably efficient, the latter appears to us to be a rather unnecessary procedure. We gather that the company is prepared to let out, on hire, clocks suitable for this purpose for an annual rental of something under $2 l$. per clock. This seems rather expensive for sub. scribers who require a number of clocks, as must be so in the majority of cases, for the whole of the utility of a synchronisation scheme depends upon every clock showing the same time.

We observe that some of the reports in the daily Press hailed the inauguration of this company as something entirely novel, but, as readers of NATURE will remember, the scheme is not at all a new one; in fact, the Post Office authorities have for a long time been synchronising their old clocks, and it seems desirable to place on record 
again that the Standard Time Co. has offered the public time service in London for many years. Then many of the electric clock firms, notably the Silent Clock Co., the Synchronome Co., and the Aron Time Distribution Co., have for a considerable time offered trustworthy synchronised Greenwich clocks to the public at rates which are, we believe, lower than those quoted by the new company. We wish every success, however, to a laudable endeavour to ensure accuracy in time-keeping,

\section{ARCTIC TIDES. ${ }^{1}$}

THE Coast and Geodetic Survey of the United States has just published the summarised account of the tides of the Arctic Ocean, based on the observations made by Peary's expedition and on those by Messrs. Mikkelsen and Leffingwell at Flaxman Island, to the north of Alaska. The recent Russian observations at Taimur Bay and on one of the New Siberian Islands are not yet available for inclusion. Peary's observations were made at Cape Sheridan, Port Aldrich (near Cape Columbia), Cape Bryant, Cape Morris Jesup, and Fort Conger for periods ranging from seven and a half months, November 12, 1908, to June 30, 1909, at Cape Sheridan, to fourteen days at Fort Conger; and hourly heights of the tide are given, as well as for Flaxman Island in Ig06. These are followed by a table giving the principal harmonic constants for all stations north of the sixtieth parallel where such constants are at present available, and fifty-four of these have been collected. Besides this, however, the same region furnishes a long range of data from many points which have been obtained by successive explorers, and these have been brought together to show the intervals, ranges, tidal hours, \&c., from all published sources, and to deduce from them the mean ranges of the semi-daily tide and the mean tidal hours.

A co-tidal chart from the Pole to latitude $65^{\circ}$ shows the results arrived at by means of lines giving the Greenwich lunar time of mean high water, and on this chart a large area of about half a million square miles between Alaska and the Pole is represented as being land but slightly submerged. The following facts are quoted as showing the necessity for such land or shoals: at Point Barrow the flood stream comes from the west; the range of the semi-daily tide at Bennett Island is 2.5 feet, whereas it is but 0.4 foot at Point Barrow and 0.5 foot at Flaxman Island; the observed tidal hours and ranges of tide show that the semi-daily tide is not propagated to the Alaskan coast directly across a deep and uninterrupted polar basin. Not only the position of such a land area is indicated, but its approximate shape is given as roughly trapezoidal, for certain points are suggested by velocity and direction of currents, by Peary's Crocker's Land, and by some of his soundings.

This paper provides a useful and instructive summary of the tidal movements of the Arctic Ocean so far as they are known, and makes a very suggestive addition to our knowledge of the distribution of north polar lands.

\section{AVIATION NOTES.}

M R. WINSTON CHURCHILL has wisely amended his "Aërial Navigation Bill," and transformed a measure which, in its original form, promised to kill aërial navigation into one of comparatively small importance. The Bill as it now stands provides that if any person navigates any kind of air vessel over any area prescribed by order of the Home Secretary, unless he can prove that he was compelled to do so by stress of weather or other uncontrollable circumstances, he shall be guilty of an offence, and be liable to six months' imprisonment or a fine of $200 l$, or both.

The prime object of the Bill is to prevent any daring or reckless aviator from flying over the Coronation processions. It is, however, an open question whether it would succeed in its aim were it not that the Royal Aero Club has requested aviators not to do so, and has provided a penalty for disobedience-the suspension of the certifi-

1 "Arctic Tides." By Rollin A. Harris. (Washington: Coast and Gesdetic Survey, 19 זт.)

NO. 2 I7O, VOL. 86$]$ cate of proficiency. It will be perfectly obvious that an aviator could pass high over the processions without incurring any penalty whatsoever. At a height of 1500 feet and upwards the identity of the pilot would be unrecognisable.

M. Jules Védrines has performed an extraordinarily fine feat in flying from Paris to Madrid, a distance of 660 miles, in I2h. I5m., thus winning the prize offered by the Petit Parisien. The flight was accomplished on a Morane monoplane fitted with a 50 horse-power Gnome motor and an "Integrale" propeller. M. Védrines started from Issyles-Moulineaux on May 22, reaching Angoulême, 250 miles away, in $3 \mathrm{~h} .42 \mathrm{~m}$. $18 \mathrm{~s}$. The second stage, to San Sebastian (193 miles), took 3 h. $43 \mathrm{~m}$. Igs., and the final stage, on May 26, to Madrid (220 miles), took 4 h. $48 \mathrm{~m}$. $42 \mathrm{~s}$. The times given are those of actual flight; but it is satisfactory to note that the first two stages were flown with out a stop, and only one halt made in the last stage, owing to the breaking of a valve spring in the motor.

The most notable advance recently made in the improvement of aëroplanes has just been successfully tested near Versailles. M. Henry Farman has fitted a silencer to the motor of his military-type biplane, which was already furnished with a wireless telegraphy transmitter. The motor-a Renault-worked without a hitch.

A meeting of the Aërial League of the British Empire was held at the Mansion House on Wednesday of last week to promote a special Coronation appeal for $250,000 l$. for the establishment of a National Institute and Schoo of Aëronautics. The following motion (moved by Sir E. Shackleton) was put to the meeting and carried unanimously:- "That this meeting of the citizens of London and the Empire supports the principles laid down in the circular issued by the Aërial League of the British Empire, and pledges itself to do all in its power to assist the League in its efforts' on behalf of the advancement of aëronautics," as was also the following (proposed by $\mathrm{Mr}$. Joynson-Hicks, M.P.) :-" "That a Coronation fund be raised for the purpose of inaugurating a National Institute and School of Aëronautics."

\section{NEW ORGANIC COMPOUNDS OF NITROGEN.'}

$\mathrm{IN}$ the diversity of behaviour exhibited by its derivatives, nitrogen is unrivalled by any other element. This is illustrated not only by the contrasting properties of ammonia, hydrazine, and azoimide, substances composed solely of nitrogen and hydrogen in different proportions, but also by the chemical, physiological, and æsthetic variations displayed by organic compounds of nitrogen, such as nitrocellulose, indigo, azo-dyes, alkaloids, enzymes, and proteins.

Azoimide or hydrazoic acid, $\mathrm{HN}_{3}$, discovered by Curtius in 1890 , is the parent of a series comprising numerous highly reactive organic compounds, the first of whichphenylazoimide-was brought to light by Peter Griess in r866, after which date the subject lay dormant for more than twenty years. Two methods are applied commercially to the production of sodium azide; the first, described by W. Wislicenus (1892), consisting in passing nitrous oxide over heated sodamide; the second, due to Stolle and Thiele working independently (1908), depending on the interaction of hydrazine, sodium ethoxide, and an ethereal nitrite. In consequence of these, the salt, originally a chemical curiosity, may now be purchased at $40 s$. per pound, largely owing to the simple and inexpensive preparation of hydrazine devised by Raschig (1908). The principal methods by which organic derivatives of azoimide may be obtained are :-

(I) Action of nitrous acid on a substituted hydrazine, applied by Curtius to the production of numerous acyl azoimides.

(2) Addition of hydrazoic acid to a diazonium sulphate, found by Noelting to yield aromatic azoimides quantitatively.

(3) Interaction of organic halides and sodium azide, as practised at the Royal College of Science in preparing aliphatic azoimides.

3 Abstract of a disconrse relivered at the Royal Institution on Friday May 5 , by Prof. Martin O. Forster, F.R.S. 